\title{
ANALISIS KINERJA KEUANGAN DAN STRATEGI BISNIS MANAJEMEN PADA PERUSAHAAN BIG BUBBLE DIVE DI GILI TRAWANGAN
}

\author{
Prabu Wahyuaji Qamara Santoso \\ specialprabu31@gmail.com \\ Jurusan Akuntansi Fakultas Ekonomi dan Bisnis Universitas Mataram \\ Animah \\ animahmtr@unram.ac.id \\ Jurusan Akuntansi Fakultas Ekonomi dan Bisnis Universitas Mataram \\ Yusli Mariadi \\ yuslimariadi@unram.ac.id \\ Jurusan Akuntansi Fakultas Ekonomi dan Bisnis Universitas Mataram
}

\begin{abstract}
ABSTRAK
PT. Big Bubble Dive adalah perusahaan yang bergerak di bidang jasa menyelam di Gili Trawangan, Provinsi Nusa Tenggara Barat. Namun, ketatnya persaingan memaksa PT. Big Bubble Dive untuk memaksimalkan kinerja perusahaan dan menentukan manajemen strategi yang tepat. Tujuan dari penelitian ini adalah untuk menganalisa kinerja keuangan perusahaan periode 2015-2018 menggunakan ratio keuangan seperti Current Ratio, ROA, ROE dan Debt-Equity Ratio serta untuk menentukan strategi bisnis manajemen perusahaan menggunakan Matriks SWOT, Matriks IFAS, Matriks EFAS dan Matriks IE. Hasil penelitian menujukan bahwa rasio keuangan PT. Big Bubble Dive periode 2015-2018 pada Current Ratio, yaitu $1.443 \%$ tahun $2015,921 \%$ tahun $2016,1.344 \%$ tahun 2017 , dan $1.770 \%$ tahun $2018, R O A$ sebesar $7,51 \%$ tahun $2015,3,29 \%$ tahun $2016,9,61 \%$ tahun 2017 , dan $12,74 \%$ tahun 2018 , ROE sebesar $34,81 \%$ tahun 2015, 3,96\% tahun 2016, 13,14\% tahun 2017 dan 24,53\% tahun 2018, Debt-Equity Ratio sebesar $402,21 \%$ tahun 2015, 41,97\% tahun 2016, 40,01 tahun 2017 dan 94,23\% tahun 2018. Strategi bisnis manajemen yang ditetapkan adalah strategi intensif yang meliputi penetrasi pasar dengan memperluas market share melalui pemasaran atau promosi maupun pengembangan produk atau jasa agar tidak terjadi kejenuhan.

Kata Kunci: kinerja keuangan, Current Ratio, ROA, ROE, Debt-Equity, startegi bisnis manajemen,

Matriks $\quad$ SWOT, Matriks IFAS, Matriks EFAS, Matriks IE

ABSTRACT
\end{abstract}

PT. Big Bubble Dive is a company engaged in diving services in Gili Trawangan, West Nusa Tenggara Province. However, intense competition forced PT. Big Bubble Dive to maximize company performance and determine the right management strategy. The purpose of this study is to analyze the company's financial performance for the 2015-2018 period using financial ratios such as Current Ratio, ROA, ROE and Debt-Equity Ratio and to determine the company's business management strategy using the SWOT Matrix, IFAS Matrix, EFAS Matrix and IE Matrix. The results showed that the financial ratios of PT. Big Bubble Dive for the 2015-2018 period in the Current Ratio, namely 1,443\% in 2015, 921\% in 2016, 1,344\% in 2017, and 1,770\% in 2018, ROA of 7.51\% in 2015, 3.29\% in 2016, 9, 61\% in 2017, and 12.74\% in 2018, ROE of $34.81 \%$ in 2015, 3.96\% in 2016, 13.14\% in 2017 and 24.53\% in 2018, Debt-Equity Ratio of 402 , $21 \%$ in 2015, 41.97\% in 2016, 40.01 in 2017 and 94.23\% in 2018. The established business management strategy is an intensive strategy that includes market penetration by expanding market share through marketing or promotion or product development or services to avoid saturation.

Keywords: $\quad$ financial performance, Current Ratio, ROA, ROE, Debt-Equity, business management strategy, SWOT Matrix, IFAS Matrix, EFAS Matrix, IE Matrix

\section{PENDAHULUAN}

Indonesia merupakan negara yang memiliki 17.504 pulau, sementara pulau yang telah berpenghuni sebanyak 2.342. Pulau-pulau tersebut dibatasi oleh 12 lautan dan 47 
selat dengan garis pantai sepanjang $95.181 \mathrm{~km}$ dan luas wilayah laut sebesar 5,8 juta km (Dewa, dkk, 2018). Dengan kondisi seperti ini, Indonesia memiliki potensi ekonomi yang sangat besar khususnya di bidang pariwisata. Jika masing-masing daerah bisa memaksimalkan potensinya tentu menjadi roda penggerak perekonomian.

Daerah-daerah wisata yang sudah terkenal hingga mancanegara seperti Pulau Bali memiliki sejuta keindahan pantai serta wisata budaya, Pulau Komodo berada di Provinsi Nusa Tenggara Timur, Kepulauan Raja Ampat berada di Provinsi Papua Barat memiliki daya tarik bagi wisatawan domestik maupun mancanegara untuk merasakan pengalaman mengarungi dunia bawah laut serta hotel berbintang. Lalu, Pulau Lombok di Nusa Tenggara Barat yang menawarkan banyak sekali daerah wisata seperti, Pantai Senggigi, wisata budaya di Taman Narmada, wisata kerajinan gerabah di daerah Banyumulek dan pesona tiga gili yaitu, Gili Trawangan, Gili Meno dan Gili Air.

Provinsi Nusa Tenggara Barat sendiri merupakan salah satu provinsi di Indonesia.Secara astronomis Nusa Tenggara Barat terletak antara $8^{\circ} 10^{\prime}-9^{\circ} 5^{\prime}$ Lintang Selatan dan antara $115^{\circ} 46^{\prime}-119^{\circ} 05^{\prime}$ Bujur Timur. Nusa Tenggara Barat terdiri dari 10 kabupaten/ kota yang terletak di dua pulau besar yaitu Pulau Lombok (Lombok Barat, Lombok Tengah, Lombok Timur, Lombok Utara dan Kota Mataram) dan Pulau Sumbawa (Sumbawa, Dompu, Bima, Sumbawa Barat dan Kota Bima). Selain dua pulau besar tersebut, Nusa Tenggara Barat juga terdiri dari ratusan pulau kecil, dimana dari 280 pulau yang ada terdapat 32 pulau yang dihuni oleh masyarakat. Selain itu Provinsi Nusa Tenggara Barat khususnya Pulau Lombok merupakan salah satu destinasi terfavorit di dunia, dimana Pulau Lombok mendapatkan dua penghargaan dalam ajang World Halal Travel Awards (WHTA) pada tahun 2015. Lombok memenangkan penghargaan dalam kategori World Best Halal Tourism Destination dan World Best Halal Honeymoon Destination (http://www.disbudpar.ntbprov.go.id/).

Berdasarkan laman resmi Dinas Pariwisata Nusa Tenggara Barat pada tahun 2016 jumlah wisatawan domestik dan mancanegara sebanyak 2.210.527 orang, tahun 2017 sebanyak 3.094.437 orang, tahun 2018 sebanyak 2.812.379 orang dan pada tahun 2019 triwulan kedua sebanyak 1.450 .830 orang.

Perkembangan bisnis sekolah menyelam (scuba diving shop) yang pesat di Gili Trawangan menimbulkan banyak perusahaan yang bergerak dibidang yang sama, seperti Trawangan Dive, Blue Marline Dive, Diversia, DSM Dive Gili Trawangan \& Lombok, Gili Divers. Banyaknya jenis usaha di bidang yang sama menuntut para pelaku usaha untuk lihai menerapkan strategi bisnis manajemen yang tepat baik dari segi pemasaran, sumber daya manusia, pemanfaatan sarana dan prasarana yang dimiliki guna menunjang kinerja perusahaan dalam menghadapi ketatnya persaingan pasar.

Dalam penelitian ini, peneliti menggunakan PT. Big Bubble Dive. Terletak di Gili Trawangan, Desa Gili Indah, Kecamatan Pemenang, Kabupaten Lombok Utara, Provinsi Nusa Tenggara Barat merupakan salah satu dari sekian banyak perusahaan penyedia jasa sekolah menyelam (scuba diving shop). Berdiri sejak tahun 2001, Big Bubble Dive memiliki segudang pengalaman dalam berbisnis maupun dalam melayani para wisatawan, tidak heran perusahaan Big Bubble Dive dianugerahi penghargaan 5 Star Dive Resort atau sekolah menyelam berbintang 5 dari induk organisasi menyelam dunia $(P A D I)$. 


\section{Risinac}

Vol. 1 No. 4 Desember 2021

\section{TINJAUAN LITERATUR}

\section{Teori Keagenan (Agency Theory)}

Teori keagenan (agency theory) mengungkapkan adanya hubungan antara principal (pemilik perusahaan atau pihak yang memberikan mandat) dan agen (manajer perusahaan atau pihak yang menerima mandat) yangdilandasi dengan adanya pemisahan kepemilikan dan pengendalian perusahaan, pemisahan penanggung risiko, pembuatan keputusan dan pengendalian fungsi-fungsi. Pihak prinsipal juga dapatmembatasi divergensi kepentingannya dengan memberikan tingkat insentif yang layak kepada agen dan bersedia mengeluarkan biaya pengawasan untuk mencegah kecurangan yang dilakukan oleh agen. Adanya pemisahan antara fungsi kepemilikan (ownership) dan fungsi pengendalian (control) dalam hubungan keagenan sering menimbulkan masalahmasalah keagenan (agency problems).

\section{Laporan Keuangan}

Menurut PSAK 1 (2015:1-3) laporan keuangan adalah suatu penyajian terstruktur dari posisi keuangan dan kinerja keuangan suatu entitas.

Komponen laporan keuangan menurut PSAK 1 (2015:1-3) sebagai berikut:

1. Laporan posisi keuangan pada akhir periode.

2. Laporan laba rugi dan penghasilan komprehensif lain selama periode.

3. Laporan perubahan ekuitas selama periode.

4. Laporan arus kas selama periode.

5. Catatan atas laporan keuangan, berisi ringkasan kebijakan akuntansi yang signifikan dan informasi penjelasan lain.

Laporan posisi keuangan pada awal periode terdekat sebelumnya ketika entitas menerapkan suatu kebijakan akuntansi secara retrospektif atau membuat penyajian kembali pos-pos laporan keuangan, atau ketika entitas mereklasifikasi pos-pos dalam laporan keuangannya sesuai dengan paragraf 40A-40D.

Laporan keuangan disusun dengan tujuan untuk memberikan informasi terkait dengan posisi keuangan, kinerja dan perubahan posisi keuangan suatuentitas yang berguna untuk pengambilan keputusan para pemakainya. Keputusan yang diambil oleh para pemakai laporan keuangan sangat bervariasi, tergantung kepentingan mereka. Informasi keuangan yang ada pada laporan keuangan harus memiliki karakteristik tertentu agardapat memenuhikebutuhan pemakainya. Karakteristik yang harus dipenuhi suatu informasi yang ada pada laporan keuangan ditetapkan dalam kerangka dasar penyusunan dan penyajian laporan keuangan atau IFRS Framework (Purba, 2010: 27).

\section{Kinerja Keuangan}

Pengertian kinerja keuangan menurut Muslich (2013: 44) bahwa: Kinerja keuangan adalah prestasi keuangan yang tergambar dalam laporan keuangan perusahaan yaitu neraca rugi-laba dan kinerja keuangan menggambarkan usaha perusahaan (operation income). Profitability suatu perusahaan dapat diukurdengan menghubungkan keuntungan yang diperoleh dari kegiatan pokok perusahaan dengan kekayaan asset yang digunakan untuk menghasilkan keuntungan.

Kinerja keuangan sebuah perusahaan dijelaskan oleh Sawir (2011: 1) sebagai ukuran mengenai seberapa jauh perusahaan-perusahaan berada dari batas normal agar perusahaan dapat dikatakan sehat dan berjalan baik sehingga dapat memenuhi kewajibannya dan menghasilkan keuntungan di masa yang akan datang.

Kerangka Konseptual 


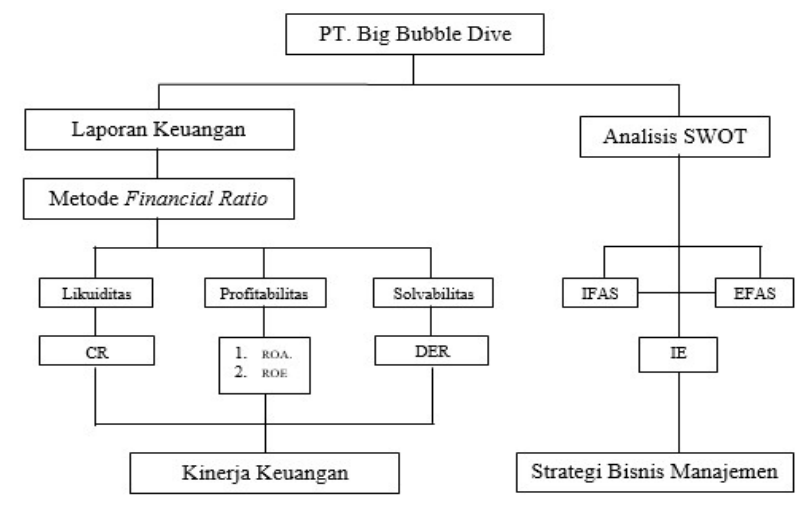

\section{METODE PENELITIAN}

Jenis penelitian ini adalah penelitian studi kasus dengan pendekatan kuantitatif deskriptif. Penelitian ini dilakukan pada PT. Big Bubble Dive yang berada di Gili Trawangan, Desa Gili Indah, Kecamatan Pemenang, Kabupaten Lombok Utara, Provinsi Nusa Tenggara Barat.

Jenis data yang dibutuhkan pada penelitian ini adalah data kualitatif dan data kuantitatif. Metode pengumpulan data adalah wawancara, observasi dan dokumentasi.

\section{Prosedur Analisis Data}

Analisis Kinerja Keuangan Menggunakan Financial Ratio

Rasio Likuiditas (Liquidity Ratios)

Current Ratio

Rasio ini mengindikasikan bahwa dari setiap hutang lancar dapat ditutupi oleh aktivaaktiva yang diperkirakan bisa diubah menjadi uang tunai dalam waktu singkat atau dengan kata lain dapat dirumuskan sebagai berikut:

Current Ratio $=\frac{\text { Aktiva Lancar }}{\text { Hutang Lancar }} \times 100 \%$

Rasio Profitabilitas

Return on Assets (ROA)

Rasio ini merupakan indikator umum profitabilitas aset perusahaan jasa dengan formula adalah sebagai berikut:

Return of Assets $(R O A)=\frac{\text { Laba Bersih Setelah Bungan dan Pajak }}{\text { Total Aset }} \times 100 \%$

Return on Equity (ROE)

$R O E$ merupakan rasio profitabilitas utama yang membandingkan antara laba perusahaan dengan modal perusahaan sendiri. Dapat diformulasikan dengan rumus sebagai berikut:

Return of Equity $=\frac{\text { Laba Bersih Setelah Pajak }}{\text { Jumlah Aktiva }} \times 100 \%$

Rasio Solvabilitas

Rasio ini mengindikasikan kemampuan modal sendiri untuk memenuhi kewajiban perusahaan yang dapat dirumuskan sebagai berikut:

Debt Equity Ratio $=\frac{\text { Total Libalitas }}{\text { Total Ekuitas }} \times 100 \%$

Analisis Strategi Bisnis Manajemen

Analisis strategi bisnis manajemen pada perusahaan PT. Big Bubble Dive dengan alat ukur Matriks SWOT yang di dalamnya terdapat Matriks IFAS dan EFAS serta Matrik IE. Matriks SWOT. 


\begin{tabular}{|c|c|c|}
\hline $\begin{array}{l}\text { IFAS } \\
\text { EFAS }\end{array}$ & $\begin{array}{c}\text { Strengths (S) Tentukan } \\
\text { 5-10 Faktor-Faktor } \\
\text { Kekuatan Internal }\end{array}$ & $\begin{array}{c}\text { Weaknesses }(\mathbf{W}) \\
\text { Tentukan 5-10 } \\
\text { Faktor-Faktor } \\
\text { Kelemahan Internal }\end{array}$ \\
\hline $\begin{array}{l}\text { Opportunities (O) } \\
\text { Tentukan 5-10 } \\
\text { Faktor-faktor } \\
\text { Peluang Eksternal }\end{array}$ & $\begin{array}{l}\text { Strategi SO } \\
\text { Menciptakan strategi yang } \\
\text { menggunakan kekuatan } \\
\text { untuk memanfaatkan } \\
\text { peluang. }\end{array}$ & $\begin{array}{l}\text { Strategi WO } \\
\text { Menciptakan strategi yang } \\
\text { meminimalkan kelemahan } \\
\text { untuk memanfaatkan } \\
\text { peluang. }\end{array}$ \\
\hline $\begin{array}{l}\text { Treaths }(\mathrm{T}) \\
\text { Tentukan 5-10 } \\
\text { Faktor-faktor } \\
\text { Ancaman Eksternal }\end{array}$ & $\begin{array}{l}\text { Strategi ST } \\
\text { Menciptakan strategi yang } \\
\text { menggunakan kekuatan } \\
\text { untuk mengatasi ancaman. }\end{array}$ & $\begin{array}{l}\text { Strategi WT } \\
\text { Menciptakan strategi yang } \\
\text { meminimalkan kelemahan } \\
\text { dan menghindari } \\
\text { ancaman. }\end{array}$ \\
\hline
\end{tabular}

Matriks IFAS

\begin{tabular}{|c|c|c|c|}
\hline $\begin{array}{c}\text { FAKTOR-FAKTOR STRATEGI } \\
\text { INTERNAL }\end{array}$ & BOBOT & RATING & \begin{tabular}{|l} 
BOBOT \\
X \\
RATING
\end{tabular} \\
\hline \begin{tabular}{|l}
\multicolumn{2}{l}{ KEKUATAN } \\
$1 . \quad$ Kekuatan1 \\
2. $\quad$ Kekuatan2 \\
3. $\quad$ Kekuatan3 4. Kekuatan4 \\
Kekuatan5 \\
Kekuatan 6-10
\end{tabular} & $\begin{array}{l}\operatorname{xxx} x x x \\
\operatorname{xxx} x x x \\
\operatorname{xxx}\end{array}$ & $\begin{array}{c}\operatorname{xxx} \operatorname{xxx} x x x \\
\operatorname{xxx} x x x\end{array}$ & $\begin{array}{l}\operatorname{xxx} x x x \\
\operatorname{xxx} x x x \\
\operatorname{xxx}\end{array}$ \\
\hline \begin{tabular}{|l|} 
KELEMAHAN \\
Kelemahan1 \\
Kelemahan2 \\
Kelemahan3 \\
Kelemahan4 \\
Kelemahan5 \\
Kelemahan 6-10
\end{tabular} & $\begin{array}{l}\operatorname{xxx} x x x \\
\operatorname{xxx} x x x \\
\operatorname{xxx}\end{array}$ & $\begin{array}{c}\operatorname{xxx} \operatorname{xxx} x x x \\
\operatorname{xxx} x x x\end{array}$ & $\begin{array}{l}\mathrm{xxx} \mathrm{xxx} \\
\mathrm{xxx} \mathrm{xxx} \\
\mathrm{xxx}\end{array}$ \\
\hline TOTAL & 1,00 & & $\mathrm{xxx}$ \\
\hline
\end{tabular}

Tentukan faktor-faktor perusahaan dalam kolom 1 (5 sampai dengan 10 faktor kekuatan dan kelemahan).

Bobot setiap variabel diperoleh dengan membagi jumlah rating setiap variabel dengan jumlah rating dari keseluruhan variabel dimana jumlah keseluruhan bobot variabel tidak boleh kurang dan tidak boleh lebih dari 1,00 menggunakan metode Paired Comparison.

Matriks EFAS

\begin{tabular}{|c|c|c|c|}
$\begin{array}{c}\text { FAKTOR-FAKTOR } \\
\text { STRATEGI EXTERNAL }\end{array}$ & BOBOT & RATING & $\begin{array}{c}\text { BOBOT X } \\
\text { RATING }\end{array}$ \\
\hline
\end{tabular}


Prabu Wahyuaji Qamara Santoso, dkk: Analisis Kinerja Keuangan Dan Strategi Bisnis Manejemen.....

\begin{tabular}{|c|c|c|c|}
\hline \begin{tabular}{|l} 
PELUANG \\
Peluang 1 \\
Peluang 2 \\
Peluang 3 \\
Peluang 4 \\
Peluang 5 \\
Peluang 6-10 \\
\end{tabular} & 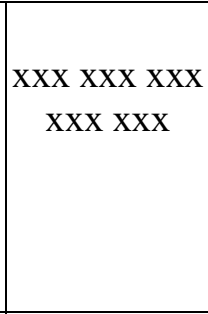 & $\begin{array}{c}\mathrm{XXX} \mathrm{XXX} \\
\mathrm{XXX} \mathrm{XXX} \\
\mathrm{XXX}\end{array}$ & $\begin{array}{c}\mathrm{XXX} \mathrm{XXX} \mathrm{XXX} \\
\mathrm{XXX} \mathrm{XXX}\end{array}$ \\
\hline $\begin{array}{l}\text { ANCAMAN } \\
\text { 1. Ancaman 1 2. Ancaman2 } \\
\text { Ancaman3 } \\
\text { Ancaman4 } \\
\text { Ancaman5 } \\
\text { Ancaman 6-10 }\end{array}$ & 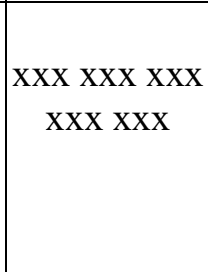 & $\begin{array}{c}\text { XXX XXX } \\
\text { XXX XXX } \\
\text { XXX }\end{array}$ & $\begin{array}{c}\mathrm{XXX} \mathrm{XXX} \mathrm{XXX} \\
\mathrm{XXX} \mathrm{XXX}\end{array}$ \\
\hline TOTAL & 1,00 & & $\mathrm{XXX}$ \\
\hline
\end{tabular}

Susunlah dalam kolom 1 (5 sampai dengan 10 peluang dan ancaman).

Bobot setiap variabel diperoleh dengan membagi jumlah rating setiap variabel dengan jumlah rating dari keseluruhan variabel menggunakan dimana jumlah keseluruhan bobot variabel tidak boleh kurang dan tidak boleh lebih dari 1,00 metode Paired Comparison Matriks IE

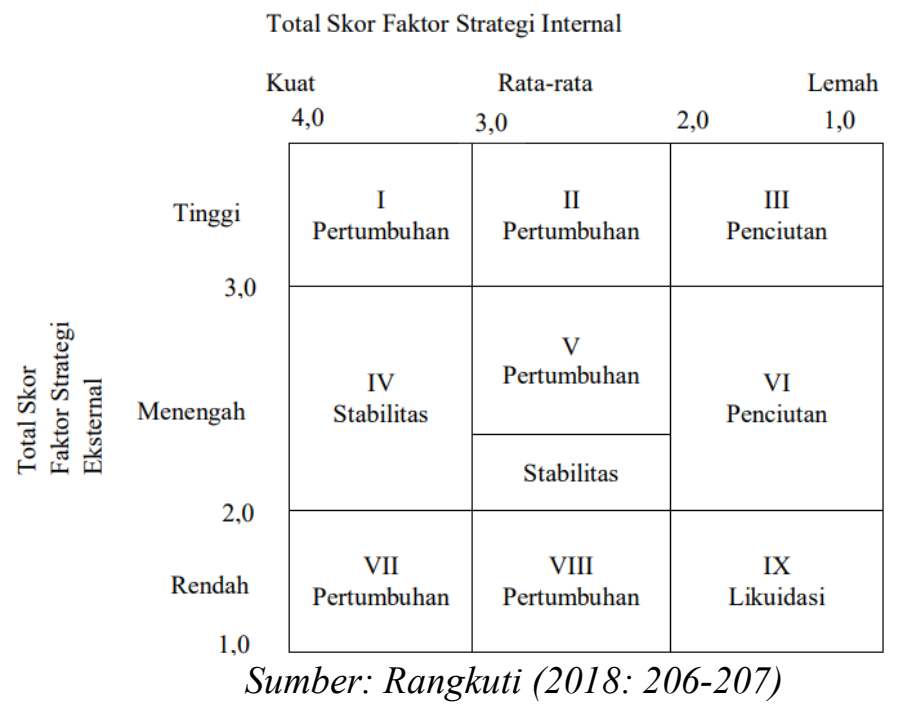

\section{HASIL DAN PEMBAHASAN}

Analisis Kinerja Keuangan Menggunakan Financial Ratio

Rasio Likuiditas

Current Ratio

Tabel 4.1

Analisis Current Ratio

PT. Big Bubble Dive

\begin{tabular}{c|cc|cc|c}
\hline Tahun & \multicolumn{2}{|c|}{ Asset Lancar } & \multicolumn{2}{|c|}{ Hutang Lancar } & \multicolumn{2}{c}{$\begin{array}{c}\text { Current } \\
\text { Ratio }(\%)\end{array}$} \\
\hline 2015 & $\mathrm{Rp}$ & 392.804 .451 & $\mathrm{Rp}$ & 27.228 .562 & 1.443 \\
\hline 2016 & $\mathrm{Rp}$ & 838.324 .129 & $\mathrm{Rp}$ & 91.043 .653 & 921 \\
\hline
\end{tabular}




\section{Risinaw}

Vol. 1 No. 4 Desember 2021

\begin{tabular}{l|lr|lr|l}
\hline 2017 & $\mathrm{Rp}$ & 426.917 .638 & $\mathrm{Rp}$ & 31.770 .772 & 1.344 \\
\hline 2018 & $\mathrm{Rp}$ & 759.568 .998 & $\mathrm{Rp}$ & 42.923 .069 & 1.770 \\
\hline \multicolumn{4}{c}{ Sumber: Data Diolah Tahun 2020 }
\end{tabular}

Dari hasil analisis current ratio ditemukan hasil bahwa selama periode 2015-2018 kinerja keuangan perusahaan sangat baik. Namun, sangat baiknya hasil analisis current ratio PT. Big Bubble Dive mengindikasikan 2 (dua) kemungkinan, yaitu pada periode bersangkutan perusahaan memang memiliki keuntungan yang besar atau perusahaan tidak menggunakan keuntungan tersebut untuk melakukan invesatasi, hal ini terlihat dari besarnya jumlah keuntungan berbanding dengan hutang lancar yang terlampu sedikit.

Rasio Profitabilitas

Return on Assets (ROA)

Tabel 4.2

Analisis Return on Assets (ROA) - PT. Big Bubble Dive

\begin{tabular}{l|cr|r|c}
\hline Tahun & Laba Bersih Setelah Pajak dan Bunga & Total Asset & $\begin{array}{c}\text { Return On } \\
\text { Assets } \\
(\text { ROA })(\%)\end{array}$ \\
\hline 2015 & Rp & 147.116 .936 & Rp 1.959 .367 .808 & 7,51 \\
\hline 2016 & Rp & 151.281 .684 & Rp 4.598.350.132 & 3,29 \\
\hline 2017 & Rp & 384.025 .063 & Rp 3.997.040.297 & 9,61 \\
\hline 2018 & Rp & 566.267 .222 & Rp 4.445.109.237 & 12,74 \\
\hline
\end{tabular}

Sumber: Data Diolah Tahun 2020

Dari hasil analisis di atas, kinerja keuangan PT. Big Bubble Dive dinilai Baik. Namun, perusahaan tidak melakukan investasi secara baik. Hal ini dibuktikan dari hasil perhitungan current ratio yang tinggi.

Return on Equity (ROE)

Tabel 4.3

Analisis Return on Equity (ROE) - PT. Big Bubble Dive

\begin{tabular}{c|cc|rr|c}
\hline \multicolumn{2}{|c}{ Analisis Return on Equity (ROE) - PT. Big Bubble Dive } \\
Tahun & Laba Bersih Setelah Pajak & & Total Aktiva & \multicolumn{1}{c}{$\begin{array}{c}\text { Return on } \\
\text { Equity (ROE) } \\
(\%)\end{array}$} \\
\hline 2015 & $\mathrm{Rp}$ & 135.794 .495 & $\mathrm{Rp}$ & 390.148 .801 & 34,81 \\
\hline 2016 & $\mathrm{Rp}$ & 128.156 .229 & $\mathrm{Rp}$ & 3.238 .867 .116 & 3,96 \\
\hline 2017 & $\mathrm{Rp}$ & 375.195 .688 & $\mathrm{Rp}$ & 2.854 .842 .054 & 13,14 \\
\hline 2018 & $\mathrm{Rp}$ & 561.440 .892 & $\mathrm{Rp}$ & 2.288 .574 .831 & 24,53 \\
\hline
\end{tabular}

Sumber: Data Diolah Tahun 2020

Dari hasil perhitungan di atas, kinerja keuangan PT. Big Bubble Dive dinilai sangat baik, ini dikarenakan perusahaan dapat menghasilkan laba secara maksimal dengan menggunakan dan mengelola modal sendiri.

Rasio Solvabilitas

Debt-Equity Ratio

Tabel 4.4

Analisis Debt-Equity Ratio

PT. Big Bubble Dive 


\begin{tabular}{r|rr|rr|c}
\hline Tahun & \multicolumn{2}{|c|}{ Total Liabilitas } & \multicolumn{2}{c|}{ Total Ekuitas } & \multicolumn{2}{c}{$\begin{array}{c}\text { Debt-Equity Ratio } \\
(\%)\end{array}$} \\
\hline 2015 & $\mathrm{Rp}$ & 1.569 .219 .007 & $\mathrm{Rp}$ & 390.148 .801 & 402,21 \\
\hline 2016 & $\mathrm{Rp}$ & 1.359 .483 .016 & $\mathrm{Rp}$ & 3.238 .867 .116 & 41,97 \\
\hline 2017 & $\mathrm{Rp}$ & 1.142 .198 .243 & $\mathrm{Rp}$ & 2.854 .842 .054 & 40,01 \\
\hline 2018 & $\mathrm{Rp}$ & 2.156 .534 .406 & $\mathrm{Rp}$ & 2.288 .574 .831 & 94,23 \\
\hline
\end{tabular}

Sumber: Data Diolah Tahun 2020

Dari hasil analisis di atas, kinerja keuangan PT. Big Bubble Dive dinilai Kurang Baik, hal ini dikarenakan hutang perusahaan yang melampaui modal yang dimiliki perusahaan, sehingga perusahaan kesulitan dalam menutup hutang yang ada dengan modal yang dimiliki.

Analisis Strategi Bisnis Manajemen Analisis SWOT

Tabel 4.5.

Analisa SWOT

\begin{tabular}{|c|c|c|}
\hline \multirow{2}{*}{$\begin{array}{l}\text { IFAS } \\
\text { EFAS }\end{array}$} & Strengths (S) & Weaknesses (W) \\
\hline & $\begin{array}{l}\text { 1. Pengalaman di dunia } \\
\text { bisnis jasa menyelam. } \\
\text { 2. Memiliki system } \\
\text { informasi yang baik. } \\
\text { 3. Memiliki SDM yang ahli } \\
\text { dibidangnya. } \\
\text { 4. Memiliki fasilitas } \\
\text { penunjang bisnis yang } \\
\text { lengkap. } \\
\text { 5. Berada di salah satu } \\
\text { destinasi wisata andalan. } \\
\text { 6. Modal usaha yang } \\
\text { dikelola dengan baik. }\end{array}$ & $\begin{array}{l}\text { 1. Perencanaan pemasaraan } \\
\text { yang kurang intensif. } \\
\text { 2. Manajer yang lebih dari } 1 \\
\text { (satu) orang dan tidak ada } \\
\text { pembagian peranan antar } \\
\text { manajer. } \\
\text { 3. Tidak memiliki sesuatu yang } \\
\text { berbeda untuk ditawarkan ke } \\
\text { para pelanggan, } \\
\text { menawarkan jasa yang sama } \\
\text { dengan para pesaing bisnis. } \\
\text { 4. Penentuan target penjualan } \\
\text { yang belum maksimal. } \\
\text { 5. Keterbatasan pemahaman } \\
\text { para staf mengenai Bahasa } \\
\text { asing selain Bahasa Inggris. }\end{array}$ \\
\hline Opportunities (O) & Strategi SO & Strategi WO \\
\hline $\begin{array}{l}\text { 1. Makin banyaknya } \\
\text { wisatawan luar maupun } \\
\text { dalam negeri yang } \\
\text { berkunjung ke Gili } \\
\text { Trawangan. } \\
\text { 2. Semakin tumbuh } \\
\text { kesadaran wisatawan } \\
\text { mengenai kehidupan } \\
\text { dunia bawah laut. } \\
\text { 3. Peran pemerintah daerah } \\
\text { dalam mengembangkan } \\
\text { pariwisata. } \\
\text { 4. Luasnya pangsa pasar baik } \\
\text { di dalam maupun luar } \\
\text { negeri. }\end{array}$ & $\begin{array}{l}\text { 1. Pertumbuhan pasar } \\
\text { dimaksimalkan dengan } \\
\text { pengalaman dalam } \\
\text { berbisnis. } \\
\text { 2. Memanfaatkan system } \\
\text { informasi untuk } \\
\text { memberikan pelayanan } \\
\text { lebih baik. } \\
\text { 3. Menjalin kerja sama } \\
\text { dengan pemerintah } \\
\text { daerah r untuk } \\
\text { mengadakan even guna } \\
\text { mempromosikan } \\
\text { pariwisata dan } \\
\text { perusahaan. }\end{array}$ & $\begin{array}{l}\text { 1. Memanfaatkan media } \\
\text { sosial untuk } \\
\text { mempromosikan bisnis. } \\
\text { 2. Memberikan pelayanan } \\
\text { berbeda dari para pesaing } \\
\text { kepada pelanggan. } \\
\text { 3. Memberikan pelatihan } \\
\text { kepada para staff berupa } \\
\text { kursus Bahasa asing selain } \\
\text { Bahasa Inggris. }\end{array}$ \\
\hline
\end{tabular}




\begin{tabular}{|c|c|c|c|}
\hline $\begin{array}{l}\text { 5. Kondisi serta suasanya } \\
\text { alam Gili Trawangan } \\
\text { menjadi daya Tarik } \\
\text { wisatawan. }\end{array}$ & & & \\
\hline Treaths $(\mathrm{T})$ & Strategi ST & Strategi WT & \\
\hline $\begin{array}{l}\text { 1. Banyaknya perusahaan } \\
\text { bergerak dibidang bisnis } \\
\text { yang sama. } \\
\text { 2. Lokasi perusahaan yang } \\
\text { berdempetan dengan } \\
\text { perusahaan pesaing. } \\
\text { 3. Berada di daerah yang } \\
\text { rawan bencana alam. } \\
\text { 4. Perubahaan nilai tukar } \\
\text { mata uang. } \\
\text { 5. Bermunculan pesaing } \\
\text { baru yang dengan jenis } \\
\text { bisnis yang sama. }\end{array}$ & $\begin{array}{l}\text { 1. Memaksimalkan } \\
\text { pengalaman berbisnis } \\
\text { serta memperbaiki } \\
\text { pelayanan sebagai nilai } \\
\text { jual. }\end{array}$ & $\begin{array}{l}\text { 1. Memperbaiki } \\
\text { internal } \\
\text { meningkatkan } \\
\text { perusahaan. }\end{array}$ & $\begin{array}{r}\text { control } \\
\text { untuk } \\
\text { kinerja }\end{array}$ \\
\hline
\end{tabular}

Setelah faktor internal dan eksternal perusahaan ditentukan, yang dilakukan adalah merumuskan strategi yang tepat bagi perusahaan dengan menggunakan Matriks Internal Strategic Factor Analysis (IFAS), Matriks Eksternal Strategic Factor Analysis (EFAS) dan Matriks Internal-Eksternal (IE).

Matriks IFAS

Tabel 4.6

Matriks Internal Strategic Factor Analysis (IFAS)

\begin{tabular}{|c|c|c|c|}
\hline $\begin{array}{c}\text { FAKTOR-FAKTOR STRATEGI } \\
\text { INTERNAL }\end{array}$ & BOBOT & RATING & SKOR \\
\hline $\begin{array}{l}\text { KEKUATAN } \\
\text { Pengalaman di dunia bisnis jasa menyelam. } \\
\text { Memiliki system informasi yang baik. } \\
\text { Memiliki SDM yang ahli dibidangnya. } \\
\text { Memiliki fasilitas penunjang bisnis yang } \\
\text { lengkap. } \\
\text { Berada di salah satu destinasi wisata } \\
\text { andalan. } \\
\text { Modal usaha yang dikelola dengan baik. }\end{array}$ & $\begin{array}{l}0,11 \\
0,08 \\
0,08 \\
0,08 \\
0,11 \\
0,08\end{array}$ & $\begin{array}{l}3 \\
3 \\
3 \\
4 \\
3\end{array}$ & $\begin{array}{l}0,44 \\
0,24 \\
0,24 \\
0,24 \\
0,44 \\
0,24\end{array}$ \\
\hline $\begin{array}{l}\text { KELEMAHAN } \\
\text { Perencanaan pemasaraan yang kurang } \\
\text { intensif. }\end{array}$ & 0,11 & 4 & 0,44 \\
\hline $\begin{array}{l}\text { Manajer yang lebih dari } 1 \text { (satu) orang dan } \\
\text { tidak ada pembagian peranan antar } \\
\text { manajer. } \\
\text { Tidak memiliki sesuatu yang berbeda } \\
\text { untuk ditawarkan ke para pelanggan, } \\
\text { menawarkan jasa yang sama dengan para } \\
\text { pesaing bisnis. } \\
\text { Penentuan target penjualan yang belum } \\
\text { maksimal. }\end{array}$ & 0,11 & 4 & 0,44 \\
\hline
\end{tabular}




\begin{tabular}{|l|c|c|c|}
\hline $\begin{array}{l}\text { Keterbatasan pemahaman para staf } \\
\text { mengenai Bahasa asing selain Bahasa } \\
\text { Inggris. }\end{array}$ & 0,08 & 3 & 0,24 \\
\hline TOTAL & $\mathbf{1 , 0 0}$ & $\mathbf{3 7}$ & $\mathbf{3 , 4 4}$ \\
\hline
\end{tabular}

Berdasarkan hasil perhitungan Matriks Internal Strategic Factor Analysis (IFAS) didapatkan 11 faktor yang terdiri dari 6 faktor kekuatan (Strengths) dan 5 faktor kelemahan (Weaknesses) dengan skor akhir 3,44. Menunjukkan bahwa respon rata-rata perusahaan dalam memanfaatkan kekuatan dan mengatasi kelamahan. Hasil ini juga menunjukkan bahwa kekuatan utama perusahaan berada di pengalaman berbisnis serta letak perusahaan disalah satu destinasi wisata unggulan dengan rating 0,44. Sedangkan kelemahan utama perusahaan adalah kurang intensifnya perencanaan pemasaran dan tidak adanya pemberian peran antar manajer dengan skor 0,44 .

Matriks EFAS

Tabel 4.7

Matriks Eksternal Strategic Factor Analysis (EFAS)

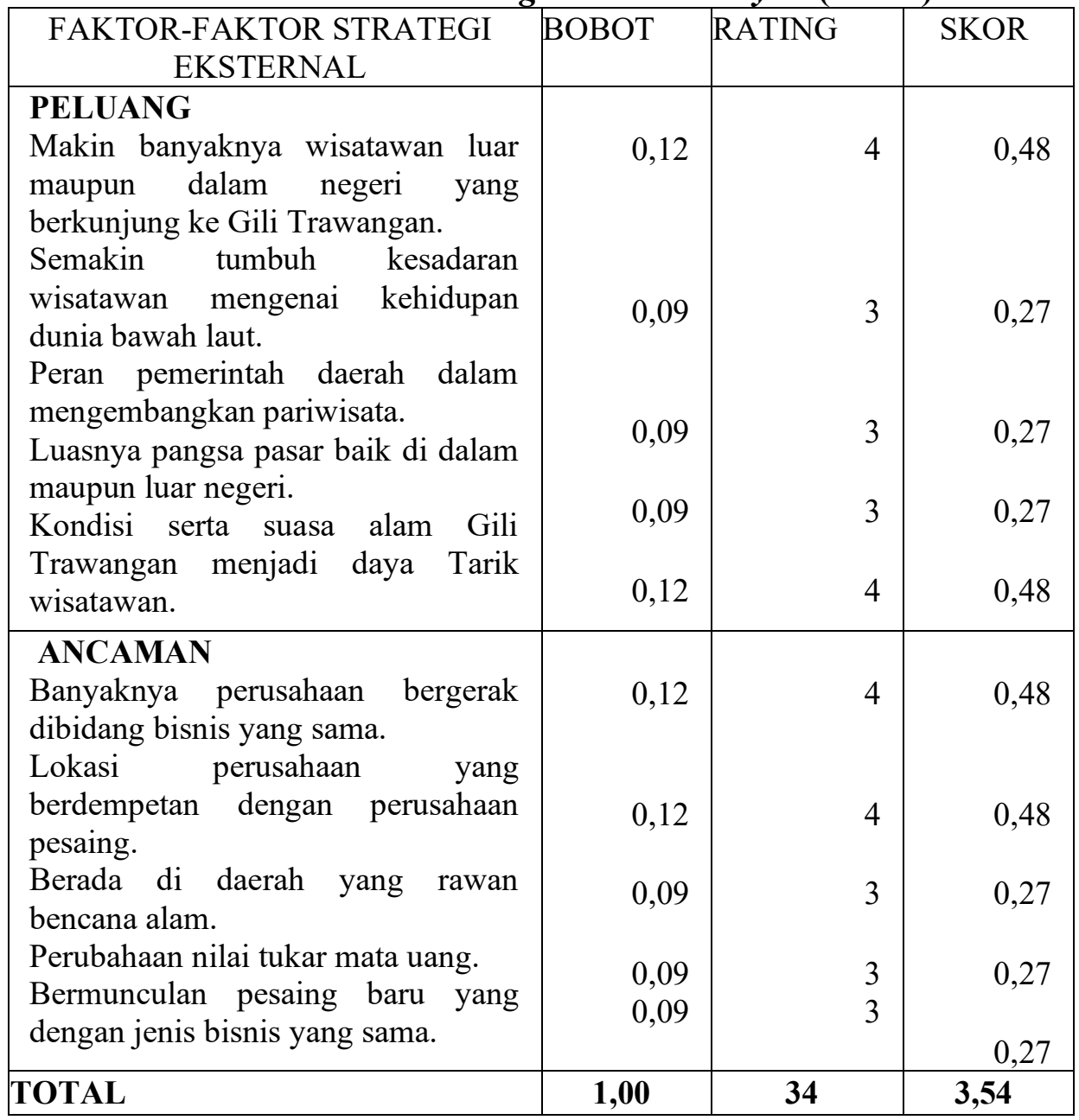

Berdasarkan hasil perhitungan Matriks Eksternal Strategic Factor Analysis (EFAS) didapatkan 10 faktor terdiri dari 5 faktor peluang (Opportunities) dan 5 faktor ancaman (Threats) dengan skor akhir 3,54. Menunjukkan bahwa respon perusahaan dalam memaksimalkan peluang serta menghadapi ancaman. Hasil ini juga menunjukkan peluang utama yang dimiliki oleh perusahaan adalah semakin banyaknya wisatawan luar maupun dalam negeri yang berkunjung ke Gili Trawangan dan kondisi serta suasana di 


\section{Risinace}

Vol. 1 No. 4 Desember 2021

Gili Trawangan yang menjadi daya tarik dengan skor akhir 0,48. Sedangkan ancama utama perusahaan adalah banyaknya para pesaing yang bergerak dibidang jasa yang sama dan lokasi perusahaan yang berdempetan dengan perusahaan lain dengan skor akhir 0,48.

Matriks IE (Internal-Eksternal).

Tabel 4.8

Matriks IE (Internal-Eksternal)

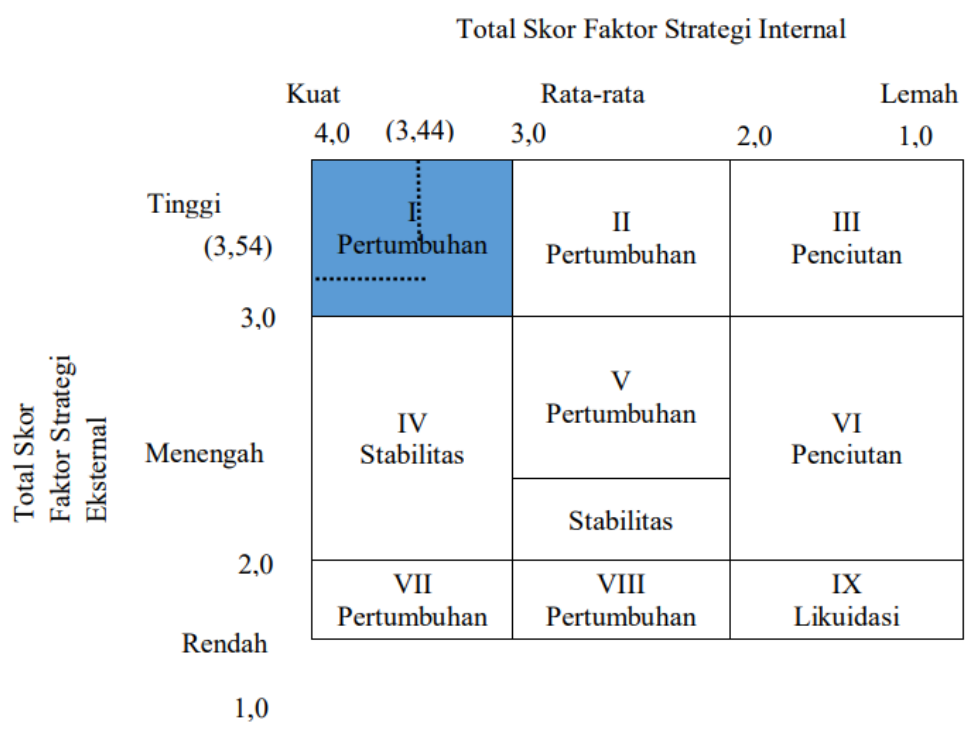

Berdasarkan hasil perhitungan dari Matriks IE (Internal-Eksternal) PT. Big Bubble Dive berada di sel 1 (growth strategy), dimana pada sel ini perusahaan hendak mencapai pertumbuhan, baik dalam penjualan, asset, profit maupun kombinasi ketiganya. Hal tersebut dapat dicapai dengan cara menurunkan harga, mengembangkan produk baru, menambah kualitas produk atau jasa, atau meningkatkan akses ke pasar yang lebih luas. Usaha lain yang dapat dilakukan adalah dengan cara meminimalkan biaya (minimize cost) sehingga dapat meningkatkan profit. Cara ini bisa dikatakan strategi yang penting apabila perusahaan berada dalam pertumbuhan yang cepat dan terdapat kecenderungan pesaing untuk melakukan perang harga dalam usaha untuk meningkatkan pangsa pasar.

\section{Penetapan Strategi Perusahaan}

Posisi perusahaan yang telah diketahui berdasarkan hasil dari Matriks IE, selanjutnya dilakukan langkah penetapan strategi perusahaan. Penetapan strategi perusahaan merupakan implikasi atas posisi perusahaan yang terdapat pada Matriks IE. Perusahaan PT Big Bubble Dive diketahui pada Matriks IE berada pada posisi cell 1, yaitu perusahaan berada pada kondisi "Pertumbuhan". Berdasarkan kondisi pertumbuhan, perusahaan hendak mencapai pertumbuhan baik dari segi penjualan, asset, profit maupun kombinasi ketiganya. Demi mencapai tujuan tersebut PT. Big Bubble Dive sebaiknya melakukan Strategi Penetrasi Pasar atau Market Penetration Strategy (Nourlette \& Hati, 2017).

Strategi Penetrasi Pasar atau Market Penetration Strategy adalah strategi pertumbuhan dimana perusahaan berkonsentrasi pada perluasan pangsa pasar untuk produk yang ada di pasar saat ini. Ini dilakukan dengan merebut pelanggan dari pesaing atau menarik pelanggan yang saat ini belum menggunakan produk. 
Strategi yang sebaiknya diterapkan perusahaan dalam menerapkan strategi penetrasi pasar adalah:

1. Memberikan promo atau potongan harga bagi pelanggan khususnya pelanggan domestik yang menggunakan produk atau jasa dalam kuantitas tertentu.

2. Membuat kartu member atau kartu pelanggan tetap yang memiliki keuntungan yaitu, potongan harga atau gratis menggunakan jasa atau

3. produk jika telah memenuhi syarat dan ketentuan yang berlaku bagi pelanggan.

4. Bekerja sama dengan travel agents untuk mengajak para pelanggan domestic khususnya masyarakat Nusa Tenggara Barat untuk menggunakan jasa dan produk dari PT. Big Bubble Dive.

5. Mengurangi produk dan jasa yang kurang diminati pelanggan dan fokus meningkatkan kualitas produk dan jasa yang menjadi pilihan utama pelanggan.

6. Menggelar event dengan periode tertentu sebagai media untuk mempromosikan produk dan jasa serta informasi mengenai harga dan keuntungan lain yang didapat pelanggan jika menggunakan jasa atau produk yang ditawarkan perusahaan.

7. Memberikan pelatihan kepada staf dengan mendatangkan narasumber yang kompeten mengenai teknik dan cara mengenai pelayanan kepada pelanggan.

\section{KESIMPULAN DAN SARAN}

\section{Kesimpulan}

Berdasarkan hasil analisis dan pembahasan yang telah dijelaskan di bab sebelumnya, maka kesimpulan dari penelitian ini adalah:

1. Pada Current Ratio PT. Big Bubble Dive periode 2015-2018 berada pada kondisi Sangat Baik. Namun, terdapat dua kemungkinan, yaitu perusahaan memiliki keuntungan besar atau perusahaan tidak efektif mengelola keuntungan untuk berinvestasi, hal ini berdasarkan asset lancar yang mengendap dalam jumlah besar.

2. Pada Return on Assets (ROA) periode 2015-2018 berada pada kondisi Baik. Tetapi, perusahaan tidak melakukan investasi secara maksimal guna mendapatkan laba yang lebih tinggi, ini berdasarkan hasil perhitungan Current Ratio yang memiliki persentase sangat tinggi.

3. Pada Return on Equity (ROE) periode 2015 -2018 berada pada kondisi Cukup Baik.

4. Pada Debt-Equity Ratio periode 2015-2018 berada pada posisi Kurang Baik.

5. Faktor-faktor lingkungan eksternal perusahaan yang dapat mempengaruhi penyusunan strategi perusahaan terbagi menjadi dua, yaitu ancaman dan peluang. Peluang berjumlah 5 faktor dengan peluang utama adalah makin banyak wisatawan yang berkunjung dengan skor 0,48 dan kondisi serta suasana Gili Trawangan dengan skor 0,48 . Ancaman berjumlah 5 faktor dengan ancaman utama adalah banyaknya perusahaan yang bergerak dibidang bisnis yang sama dengan skor 0,48 dan lokasi perusahaan yang berdempetan dengan perusahaan pesaing dengan skor 0,48 .

6. Faktor-faktor lingkungan internal perusahaan yang dapat mempengaruhi penyusunan strategi perusahaan terbagi menjadi dua, yaitu kekuatan dan kelemahan. Kekuatan berjumlah 6 faktor dengan kekuatan utama adalah pengalaman di dunia bisnis jasa menyelam dengan skor 0,44 dan berada di salah satu destinasi wisata andalan dengan skor 0,44. Kelemahan berjumlah 5 faktor dengan kelemahan utama adalah perencanaan pemasaran yang kurang intensif dengan skor 0,44 dan manajer perusahaan yang lebih dari 1 orang tanpa pembagian peranan antar manajer dengan skor 0,44 . 


\section{Risinace}

Vol. 1 No. 4 Desember 2021

7. Strategi yang sebaiknya digunakan oleh PT. Big Bubble berdasarkan analisis Matriks SWOT dan Matriks IE adalah Strategi Penetrasi Pasar atau Market Penetration.

\section{Saran}

Berdasarkan kesimpulan yang diuraikan diatas, dapat diberikan beberapa saran sebagai berikut:

1. Perusahaan perlu mengkaji serta menigkatkan kinerja keuangan khususnya pada Debt-Equity Ratio karena berdasarkan hasil penelitian kinerja keuangan perusahaan berada di kondisi yang buruk. Lalu, strategi bisnis manajemen yang sebaiknya diterapkan demi pertumbuhan perusahaan adalah strategi difirensial dalam menghadapi persaingan di segmen pasar yang sama.

2. Untuk peneliti selanjutnya yang menggunakan penelitian yang sama, disarankan untuk menambah jumlah alat ukur kinerja keuangan perusahaan serta memperpanjang periode laporan keuangan dan menambah faktor-faktor internal dan eksternal perusahaan yang nantinya akan mempengaruhi pengambilan keputusan strategi bisnis dan manajemen.

\section{REFERENSI}

Djakaman. (2000). Dasar-dasar Manajemen Keuangan Edisi Kedua. Jakarta: Salemba Empat.

Fahmi, I. (2014). Manajemen Strategis: Teori dan Aplikasi. Bandung: Alfabeta.

Gitusudarmo. (2002). Manajemen Keuangan. Yogyakarta: BPFE.

Hanafi, M. M., \& dan Abdul, H. (2016). Analisis Laporan Keuangan, Edisi Kelima. Yogyakarta: UPP STIM YKPN.

Harahap, S. S. (2012). Teori Akuntansi Laporan Keuangan, Edisi Pertama. Jakarta: Bumi Aksara.

Hitt, M. A. (2001). Manajemen Strategis: Daya Saing dan Globalisasi Konsep Edisi Pertama Buku 1. Jakarta: Salemba Empat .

Horne, V. (2012). Prinsip-prinsip Manajemen Keuangan, Edisi Ketiga belas. Jakarta: Salemba Empat.

Hunger, D. J., \& Wheelen. (2001). Manajemen Strategis Edisi Pertama Cetakan Pertama. Yogyakarta: Andi.

Indonesia, I. A. (2015). PSAK No. 1 Tentang Laporan Keuangan Edisi Revisi 2015. Jakarta: PT. Raja Grafindo.

Indonesia, I. A. (2016). SAK EMKM Edisi 2016. Jakarta: Dewan Standar Akuntansi Keuangan.

Kasmir. (2010). Analisis Laporan Keuangan, Cetakan Ketiga. Jakarta: PT. Rajagrafindo Persada.

Kusnadi, H. (2000). Pengantar Manajemen Strategi. Malang: Universitas Brawijaya .

Manuain, D. W. (2016). Analisis Laporan Keuangan Terhadap Kinerja Keuangan Pada Hotel Cahaya Bapa. Jurnal Akuntansi, Keuangan dan Audit, 56-65.

Maulina, \& Nurbayani. (2019). Analisis Profitabilitas Untuk Mengukur Kinerja Keuangan Manajemen Hotel Syariah Al Badar Di Kota Makassar. Journal of Management \& Business, 1-12.

Munawir. (2012). Analisa Laporan Keuangan, Edisi Keempat. Yogyakarta: Liberty. Munawir. (2014). Analisa Laporan Keuangan. Yogyakarta: Liberty.

Muslich, M. (2013). Manajemen Keuangan Modern. Jakarta: Penerbit Bumi Aksara.

Nafarin. (2009). Penganggaran Perusahaan. Jakarta: Salemba Empat. 
Nourlette, R. R., \& Hati, S. W. (2017). Penentuan Strategi Dengan Pendekatan Analisis SWOT Pada Hotel Nongsa Point Marina \& Resort Dalam Menghadapi Persaingan Bisnis. Jurnal Inovasi dan Bisnis, 83-102.

Permatasari, D. E., Hamid, D., \& Wilopo. (2015). Penentuan Strategi Bisnis Manajemen Hotel Dalam Menghadapi Persaingan (Studi Kasus Di Quds Royal Hotel Surabaya). Jurnal Administrasi Bisnis, 1-8.

Porter, M. E. (2008). Competetive Advantage (Keunggulan Bersaing): Menciptakan dan Mempertahankan Kinerja Unggul. Tangerang: Karisma Publishing Group.

Pudjiastuti, Suad, H., \& Enny, d. (2002). Dasar-Dasar Manajemen Keuangan. Yogyakarta: UPP AMP YKPN.

Purba, M. P. (2010). International Financial Reporting Standards: Konvergensi dan Kendala Aplikasinya di Indonesia. Yogyakarta: Graha Ilmu.

Purwanto, I. (2008). Manajemen Strategi . Bandung: CV. Yrama Widya.

Rangkuti, F. (2017). Analisis SWOT Edisi 23. Jakarta: PT. Gramedia Pustaka Utama.

Rangkuti, F. (2018). Teknik Membedah Kasus Bisnis Analisis SWOT Edisi 24. Jakarta: PT Gramedia Pustaka Utama.

Riyanto. (2011). Dasar-dasar Pembelanjaan Perusahaan, Edisi Keempat. Yogyakarta: BPFEYogyakarta.

Rooroh, L. O., Mananeke, L., \& Djurwati, S. (2019). Penentuan Strategi Bisnis Pada Rimba Papua Hotel Dalam Menghadapi Persaingan Di Timika. Jurnal Riset Ekonomi, Manajemen, Bisnis dan Akuntansi, 2711-2720.

Salusu, J. (2006). Pengambilan Keputusan Strategik Untuk Organisasi Publik dan Organisasi Non Privat. Jakarta: PT Gramedia Widiasama Indonesia.

Sawir, A. (2011). Analisis Kinerja Keuangan dan Perencanaan Keuangan Perusahaan. Jakarta: PT Gramedia Pustaka Utama.

Schmidgall, R. (2002). Hospitalty Industry Managerial Accounting. Michigan US: Educational Institute of the American Hotel \& Lodging Association.

Soemarso. (2014). Akuntansi Suatu Pengantar. Jakarta: Salemba Empat.

Suwardjono. (2010). Akuntansi Pengantar. Yogyakarta: BPFE Yogyakarta. Tamallo, E. (2017). Analisis Kinerja Keuangan Pada Hotel Grand Asia Di Makassar. Jurnal Ekonomi dan Bisnis, 40-54.

Wirawan. (2011). Evaluasi Teori, Model, Standard, Aplikasi dan Profest. Jakarta: PT Raja Grafindo Persada. 